\title{
Determination of Synergistic Inhibitory Activity of some Nanoparticles and Antibiotic Against Pathogenic Bacteria Caused Acne
}

Ahmed Shihab Al-Dinn Ahmed Awadh Al-Jobouri, Department of Biology, Tikrit University College of Education for Pure Sciences [TUCOEPS], Tikrit. Iraq.

Email: alalhmedahmed@gmail.com; Mobile: 07711775200

ORCID: http://orcid.org/0000-0002-2273-6479

Mohammed Nadhir Maaroof, Department of Biology, Tikrit University College of Education for Pure Sciences [TUCOEPS], Tikrit. Iraq.

Email: mohannednather78@yahoo.com; Mobile: 07701890060

ORCID: http://orcid.org/0000-0001-6598-2090

Correspondence author: Mohammed Nadhir Maaroof, Department of Biology, Tikrit University College of Education for Pure Sciences [TUCOEPS], Tikrit. Iraq.

Email: mohannednather78@yahoo.com; Mobile: 07701890060

Received: 30/10/2019 Accepted:27/3/2020 Published: $1^{\text {st }}$, May, 2020

\section{Abstract}

Background: Acne is a common adolescent disease with social impact on affected individual and his family. Many drug formulations available for acne treatment but with varied treatment response and associated with patient none compliance.

Aim: Determine the inhibitory effect of antibiotics and nanoparticles combination against bacteria that cause acne.

Materials and methods: This study was conducted at Laboratories of the Department of Biology/ College of Education for Pure Sciences/ University of Tikrit. 124 samples were collected by swap survey of hospitalized patients with acne in Salahuldean General Hospital during the period from $1 / 8 / 2018$ to $1 / 4 / 2019$. After the diagnosis using biochemical tests as well as Vitek2 Compact System, the ability of Gram positive and negative bacterial species that produce virulence 
factors such as Hemolysin, Urease, Biofilm, Lecithinase, Lipase and $\beta$-Lactamase were investigated.

Results: Twelve types of antibiotics were used and the isolates showed different degrees of sensitivity to antibiotics. For the inhibition of titanium dioxide nanoparticles, the results showed that $\mathrm{TiO}_{2}$ nanoparticles had the highest inhibition capacity for Grampositive bacteria, while the inhibition of Gram-negative species was relatively low. The combination of $\mathrm{TiO}_{2}$ nanoparticles and antibiotic shows inhibitory diameter ranged between 25 to $50 \mathrm{~mm}$ against Gran positive bacteria for nano concentration of 50 and $100 \mathrm{mg}$ respectively. While Gram negative bacteria show inhibitory diameter ranged between 20-30 mm for $\mathrm{TiO}_{2}$ nanoparticles concentrations were 50 and $100 \mathrm{mg}$ respectively.

Conclusion: Isolated organisms demonstrated high resistance rate to antibiotics; however, antibiotic combination with $\mathrm{TiO}_{2}$ induced synergistic inhibitory activity against Gram positive and Gram negative bacteria. And the effect was higher in gram positive as compared to gram negative bacteria. This finding suggests new drug formulation for acne treatment.

Keywords: Acne, TiO2, Staphylococcus aureus, Citrobacter freundii, Strep. Pyogenes, Ps. aeruginosa, Ps. stutzeri, Enterobacter cloacae, Staph. epidermidis, Staph. saprophyticus, Klebsiella oxytoca, Raoultella ornithinolytica

\section{Introduction}

Acne is one of the most common skin problems and defined as a disorder of the sebaceous glands of the skin resulting in increased secretions causing obstruction and inflammation of the ducts [1], attributed to chronic inflammation that occurs in the subcutaneous fat layer. It characterized by the formation of comedones, papules and pustules and often scars on the face, neck and upper area of the back and arms. Symptoms may appear in the twenties or thirties and may last for many years that are not associated with a specific age group. Although more common among the age group of adolescents, however it was found that $15 \%$ of the cases were in adults [2]. However, in some cases the acne lesions continue to appear with age progression. Acne lesions distributed mainly on the face and can spread to nearby areas such as the neck and shoulders. The most important factors in the formation of acne is the frequency of taking 
some medicinal drugs or the result of hormonal changes, as well as affected by diet composition, especially the unbalanced diet which may be attributed to stress [3].

The most common microbes that can cause inflammation in cysts or acne pimples are Staphylococcus bacteria [4], especially Staph. epidermidis, and Staph. aureus, which are naturally coexisting microbes in the nose and on human skin [5]. Recent studies and research had indicated that the delay or lack of treatment for acne cases in a timely manner has caused unpleasant side effects such as burning and redness in the face as well as the appearance of dark marks and spots in the skin that are difficult to get rid of such lesions [6]. Additionally, the acne response to available treatment approaches varies and influence by multiple factors and there was no absolute effective treatment. Thus this study was conducted to find an alternative treatment approach.

\section{Materials and Methods \\ Collection of samples}

One hundred and twenty four patients were enrolled in the study and samples were collected from people who attend to the hospital with age range of 11-24 years. The study was conducted in Salahuldean General Hospital for the period between August 2018 to April 2019. The samples were taken from pimples or comedones. The study protocol was approved by the Ethical Committee of Tikrit University College of Education for Pure Sciences. Verbal informed consent was taken from each individual before his/her enrollment in the study.

\section{Detection of the production of virulence factors}

\section{- Hemolysin production test}

The bacterial isolates to be selected for the ability to produce the hematopoietic enzyme were transplanted to the center of the prepared hematopoiesis and incubated at $37^{\circ} \mathrm{C}$ for 24 hours. The positive result is when the blood decomposes and the appearance of a colorless transparent area in the case of complete decomposition or on the appearance of a green belt in the case of partial decomposition around the colonies [7].

\section{- Urease test}

This test was used to detect the ability of bacterial isolates to produce urease enzyme which catalyzes breakdown of urea. Urea agar 
was inoculated with isolates and incubated at $37^{\circ} \mathrm{C}$ for 24 hours. The change of the medium color from yellow to pink indicates the positive reaction hence means urea catalyzed to ammonia by urease enzyme [8].

\section{- Lecithinase and Lipase production test}

Bacterial isolates were cultured on dishes containing medium egg yolk (Egg yolk agar) and incubated at $37^{\circ} \mathrm{C}$ for $48-24$ hours. The emergence of clear areas around the developing bacterial colony indicates the production of the enzyme Lecithinase. While Lipase production performed by submerging the dish with $20 \%$ Cuso $4-7 \mathrm{H} 2 \mathrm{O}$ blue aqueous sulphate solution for 20 minutes, then dried by incubator for 30 minutes after removing the excess solution, as the appearance of greenish blue color around the growth zones indicates the production of lipase enzyme [9].

\section{- Beta-lactamase production test}

An Iodometric spot method was used where a circular piece of filter paper was placed in sterile Petri dishes, then $0.02 \mathrm{~g}$ of penicillin $\mathrm{G}$ in powder form was transferred to the center of the filter paper and then drops of distilled water were added. Then part of the colony was transferred and placed in the center of the paper and mixed with penicillin, and the dishes were left at room temperature for 10 minutes. Then drops of Iodine were added and positive test shows a white spot that appears in the center of the paper after 5 minutes of incubation [10].

\section{- Detection of Bacterial biofilm production methods}

Tube method was performed by placing a loopful of bacterial inoculum from agar plate into a glass test tube containing $5 \mathrm{ml}$ of trypticase soy broth (TSB) and incubated overnight at $37^{\circ} \mathrm{C}$. Each tube was decanted, washed with phosphate buffer saline ( $\mathrm{pH} 7.2)$, stained with $0.25 \%$ Saffranin, and then gently rotated to ensure uniform staining and the contents were gently decanted. The tube were then placed upside- down to drain. The color of the inner surfaces of the tubes was observed. Biofilm formation was considered positive when a visible film lined the wall and bottom of the tube. The absence of a film or the presence of a ring at the liquid-air interface was interrupted as a negative result $(-)$. Based on biofilm production, the positive results were recorded as strong $(+++)$, moderate $(++)$ and week $(+)$ [11]. 


\section{Antibiotic Sensitivity Test}

Antibiotics susceptibility was carried out on all isolate using Kirby Bauer disc diffusion method. Results were interpreted by measuring the zone of inhibition in $\mathrm{mm}$ [12]. Twelve types of antibiotics were used in this study: Levofloxacin (LEV), Metronidazole (MET), Norfloxacin (NOR), Piperacillin (PRL), Imipenem (IPM), Azetreonam (ATM), Ofloxacin (OFX), Carbenicillin (PY), Netilmicin (NET), Neomycin (N), Azithromycin (AZM), Meropenem (MEM).

\section{Titanium dioxide $\mathrm{TiO}_{2}$ nanoparticles}

$\mathrm{TiO}_{2}$ nanoparticles were obtained from the postgraduate laboratory, Department of Biology, College of Education for Pure Sciences, University of Tikrit which was prepared from Aspergillus flavus [13].

\section{Manufacture of Titanium $\mathrm{TiO}_{2}$ Nanoparticles}

Cell-free filtration was obtained after incubation of $10 \mathrm{~g}$ of fungus strands of Aspergillus flavus and $100 \mathrm{ml}$ of $1 \mathrm{mM} 1 \mathrm{TiO}_{2}$ mineral for nanoparticle synthesis [14]. The entire mixture was transferred to a shaking incubator $(150 \mathrm{rpm})$ at $28^{\circ} \mathrm{C}$ and allowed to interact for 48 hours, another vial containing $10 \mathrm{~g}$ of wet biomass and $100 \mathrm{ml}$ of sterile distilled water (this vial was used as a control). While the third bottle was used as a control also because it contains only 100 $\mathrm{ml}$ mineral solution. All vials were incubated at $28^{\circ} \mathrm{C}$ in the dark for 96 hours with agitation $(150 \mathrm{rpm})$. The biologically transformed particles were collected periodically and monitored for their characterization [14].

\section{Results and Discussion \\ Bacterial isolates virulence}

The result showed that there is a variation in the virulence factors of the isolated bacterial species, Table 1. All tested isolates of Streptococcus pyogenes, Pseudomonas aeruginosa, and Pseudomonas stutzeri isolates completely produced hemolysin. While only 33.3\% of tested Staphylococcus aureus and 50\% of Enterobacter cloacae complex induced hemolysin. However, Staph. epidermidis, Staph. saprophyticus, Citrobacter freundii, Klebsiella oxytoca, and Raoultella ornithinolytica did not produce hemolysin.

The current study shows that all Staph. aureus, all Klebsiella Oxytoca, $71.42 \%$ of Staph.epidermidis, $40 \%$ of Staph. saprophyticus, 
and $50 \%$ of Enterobacter cloacae complex produced urease. The bacterial species Raoultella ornithinolytica, Citrobacter freundii, Psudomonas.spp, and Strep.pyogenes did not produce urease. Seven isolates (46.66\%) of Staph.aureus, two isolates (40\%) of Staph. Saprophyticus, 3 isolates (100\%) of Pseudomonas species, 4 isolates (100\%) of Enterobacter cloacae complex, 3 isolates $(60 \%)$ of Citrobacter freundii, one isolate (100\%) of Klebsiella oxytoca and single $(100 \%)$ isolate of Raoultella ornithinolytica produced biofilms. Whereas bacterial species that did not producing biofilms included Staph.epidermidis and Strep.pyogenes.

The results of the current study showed that 8 isolates $(53.33 \%)$ of Staph.aureus, 5 isolates (71.42\%) of Staph.epidermidis, 3 isolates $(60 \%)$ of Staph.saprophyticus, 3 isolates $(100 \%)$ of Pseudomonas species, two isolates (50\%) of Enterobacter cloacae complex, 5 isolates $(50 \%)$ of the type Citrobacter freundii, one isolate $(100 \%)$ of Raoultella ornithinolytica, produce the lecithinase enzyme. While the results showed that Klebsiella oxytoca and Strep.pyogenes did not produce lecithinase. The results also showed that 8 isolates $(53.33 \%)$ of Staph.aureus, 5 isolates $(71.42 \%)$ of Staph.epidermidis, 3 isolates (60\%) of Staph.saprophyticus, 3 isolates $(100 \%)$ of Pseudomonas.spp, 5 isolates (50\%) of Citrobacter freundii, and 2 isolates (50\%) of Enterobacter cloacae complex produced lipase enzyme. Whereas, Strep.pyogenes, Raoultella ornithinolytica and Klebsiella oxytoca did not produce lipase enzyme.

The results of the current study showed that 15 isolates (100\%) of Staph. aureus isolates, 5 isolates $(71.42 \%)$ of Staph. epidermidis isolates, 3 isolates $(60 \%)$ of Staph.saprophyticus produced betalactamase. The results also showed that Raoultella ornithinolytica, Klebsiella oxytoca, Pseudomonas species, Enterobacter cloacae complex, and Citrobacter freundii did not produce beta-lactamase.

\section{Antibiogram}

The sensitivity test for Gram-positive bacteria isolates against tested antibiotics indicated a varied susceptibility. All Staph. aureus were resistant to 4 antibiotics, (Piperacillin, Carbenicillin, Neomycin, Azetreonam), and $80 \%$ resistance to Metronidazole. While showed a weak resistance to Netilmicin. In contrast, absolute sensitivity (100\%) to Levofloxacin, Imipenem, Ofloxacin, Azithromycin and Meropenem). Staph. saprophyticus isolates were 100\% absolute resistance to Metronidazole, Piperacillin, Carbenicillin and 
Azetreonam. While demonstrated a weak resistance of $20 \%$ to Azithromycin, and $60 \%$ and $80 \%$ to Neomycin and Netilmicin respectively. In contrast, absolute sensitivity to Levofloxacin, Meropenem. Imipenem and Ofloxacin was demonstrated.

Staph. epidermidis with absolute resistance to Piperacillin, Carbenicillin, Neomycin and Azetreonam and $80 \%$ resistance to Metronidazole, $40 \%$ resistance to Netilmicin. Meropenem, Norfloxacin, and 100\% absolute sensitivity to Ofloxacin and Azithromycin. Strep. pyogenes isolates showed 100\% absolute resistance to Neomycin, Piperacillin, Carbenicillin and Metronidazole; and $92.3 \%, 69.2 \%$ and $77 \%$ to Azetreonam, Netilmicin and Azithromycin respectively. It also showed low resistance of $15.3 \%$ and $23 \%$ to Imipenem and Meropenem. However, $100 \%$ sensitivity was demonstrated to Levofloxacin, Norfloxacin and Ofloxacin.

The Gram-negative isolates tested in this study were absolutely resistant to Netilmicin, Azithromycin Neomycin, Piperacillin, and Metronidazole. In contrast, $100 \%$ sensitive to Ofloxacin, Norfloxacin and Levofloxacin was demonstrated. In addition, it showed variation in sensitivity to other antibiotics. All Citrobacter freundii isolates were resistance to Neomycin, Netilmicin, Carbenicillin, Piperacillin and Metronidazole. While $60 \%, 60 \%, 90 \%$ and $80 \%$ of the isolates were resistant to Azetreonam. Imipenem, Meropenem, Azithromycin, respectively. However, low sensitivity of $30 \%, 20 \%$ and $10 \%$ against Ofloxacin, Norfloxacin, Levofloxacin were shown.

Enterobacter cloacae complex tested isolates showed 100\% resistance to Neomycin Netilmicin, Carbenicillin, Piperacillin, Metronidazole. While, $50 \%, 50 \%, 75 \%$ and $25 \%$ of the isolates were resistant to Azetreonam, Azithromycin, Meropenem and Imipenem respectively. In contrast, $100 \%$ sensitivity to Ofloxacin, Norfloxacin Levofloxacin was demonstrated. One isolate of Raoultella ornithinolytica was $100 \%$ sensitive to Norfloxacin Levofloxacin, Imipenem, Ofloxacin, Netilmicin and Meropenem, and showed 100\% absolute resistance to Metronidazole, Piperacillin. Azetreonam and Carbenicillin.

Ps. aeruginosa isolates showed absolute resistance to Metronidazole, Piperacillin, Azetreonam, Carbenicillin, Neomycin, Azithromycin. While shows a resistance rate of $44 \%, 44.3 \%$ and $22.2 \%$ to Meropenem, Netilmicin and Imipenem, respectively. Absolute sensitivity to Levofloxacin, Norfloxacin and Ofloxacin was 
demonstrated.. While single isolation of Ps. stutzeri showed absolute resistance to Metronidazole, Piperacillin, Azetreonam, Carbenicillin, Neomycin and Azithromycin, and resistance rate of $22 \%, 22.3 \%$ and $11.1 \%$ to Meropenem. Netilmicin and Imipenem, respectively. While, shows $100 \%$ sensitivity to Levofloxacin, Norfloxacin and Ofloxacin.

The single bacterial isolate of Klebsiella oxytoca showed $100 \%$ resistance to Metronidazole, Netilmicin, Piperacillin, Carbenicillin, Neomycin, Azetreonam and Azithromycin.

Table 1. Virulence factors of the tested bacterial isolates

\begin{tabular}{|c|c|c|c|c|c|c|c|}
\hline \multicolumn{6}{|c|}{ Virulence Factor } & \multirow[b]{2}{*}{ No } & \multirow{3}{*}{ Bacterial Species } \\
\hline 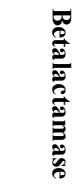 & : & 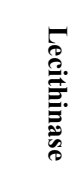 & 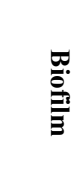 & 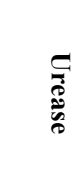 & 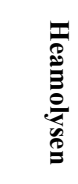 & & \\
\hline$\%+$ & $\%+$ & $\%+$ & $\%+$ & $\%+$ & $\%+$ & & \\
\hline 100 & 53.3 & 53.3 & 64.7 & 100 & 33.3 & 15 & $\begin{array}{l}\text { Staphylococcus } \\
\text { aureus }\end{array}$ \\
\hline 71.4 & 71.4 & 71.4 & $\mathbf{0}$ & 71.4 & $\mathbf{0}$ & 7 & $\begin{array}{l}\text { Staphylococcus } \\
\text { epidermidis }\end{array}$ \\
\hline 60 & 60 & 60 & 40 & 40 & $\mathbf{0}$ & 5 & $\begin{array}{l}\text { Staphylococcus } \\
\text { saprophyticus }\end{array}$ \\
\hline $\mathbf{0}$ & $\mathbf{0}$ & $\mathbf{0}$ & $\mathbf{0}$ & $\mathbf{0}$ & 100 & 13 & $\begin{array}{l}\text { Streptococcus } \\
\text { pyogenes }\end{array}$ \\
\hline $\mathbf{0}$ & 50 & 50 & 60 & $\mathbf{0}$ & $\mathbf{0}$ & 5 & Citrobacter freundii \\
\hline $\mathbf{0}$ & 50 & 50 & 100 & 50 & 50 & 4 & $\begin{array}{l}\text { Enterobacter } \\
\text { cloacae complex }\end{array}$ \\
\hline $\mathbf{0}$ & $\mathbf{0}$ & 100 & 100 & $\mathbf{0}$ & 0 & 1 & $\begin{array}{l}\text { Raoultellaornithinol } \\
\text { ytica }\end{array}$ \\
\hline $\mathbf{0}$ & 100 & 100 & 100 & $\mathbf{0}$ & 100 & 2 & $\begin{array}{l}\text { Pseudomonas } \\
\text { aeruginosa }\end{array}$ \\
\hline $\mathbf{0}$ & 100 & 100 & 100 & $\mathbf{0}$ & 100 & 1 & $\begin{array}{l}\text { Pseudomonas } \\
\text { stutzeri }\end{array}$ \\
\hline $\mathbf{0}$ & $\mathbf{0}$ & $\mathbf{0}$ & 100 & 100 & $\mathbf{0}$ & 1 & Klebsiella oxytoca \\
\hline
\end{tabular}



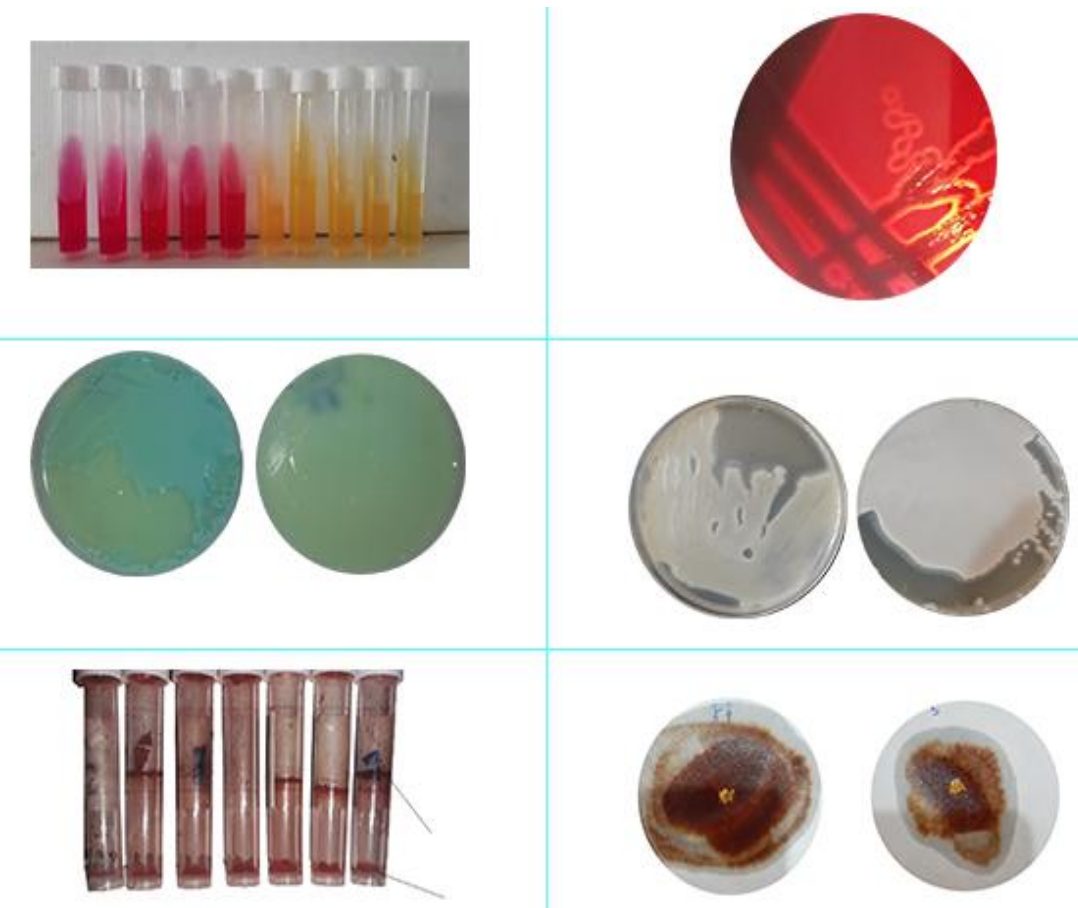

Figure.1. Detection of Virulence factors

Table 2. Antibiotic sensitivity test

\begin{tabular}{|l|c|c|c|c|c|}
\hline $\begin{array}{c}\text { Antibiotics } \\
\text { in mg }\end{array}$ & $\begin{array}{c}\text { Staph. } \\
\text { aureus } \\
\text { NO[44] }\end{array}$ & $\begin{array}{c}\text { Staph. } \\
\text { epidermidis } \\
\text { NO [21] }\end{array}$ & $\begin{array}{c}\text { Staph. } \\
\text { saprophyticus } \\
\text { NO [17] }\end{array}$ & $\begin{array}{c}\text { Strep. } \\
\text { pyogenes } \\
\text { NO [13] }\end{array}$ & $\begin{array}{c}\text { Citrobac. } \\
\text { freundii } \\
\text { NO [10] }\end{array}$ \\
\cline { 2 - 6 } & $\%$ & $\%$ & $\%$ & $\%$ & $\%$ \\
\hline ATM 30 & 100 & 100 & 100 & 92.3 & 60 \\
\hline MEM 10 & 0 & 40 & 0 & 23 & 90 \\
\hline AZM 30 & 0 & 0 & 20 & 77 & 80 \\
\hline N 10 & 100 & 100 & 60 & 100 & 100 \\
\hline NET 30 & 40 & 40 & $\mathbf{8 0}$ & 69.2 & 100 \\
\hline PY 25 & 100 & 100 & 100 & 100 & 100 \\
\hline OFX 10 & 0 & 0 & 0 & 0 & 30 \\
\hline IMP 10 & 0 & 0 & 0 & 15.3 & 60 \\
\hline PRL 30 & 100 & 100 & 100 & 100 & 100 \\
\hline NOR 10 & 20 & 40 & 0 & 0 & 20 \\
\hline MET 30 & $\mathbf{8 0}$ & $\mathbf{8 0}$ & $\mathbf{1 0 0}$ & 100 & 100 \\
\hline LEV 5 & $\mathbf{0}$ & $\mathbf{0}$ & 0 & 0 & 10 \\
\hline
\end{tabular}


Table. 3. The effects of $\mathrm{TiO}_{2}$ nanoparticles on the gram positive and negative bacterial isolates

\begin{tabular}{|c|c|c|c|}
\hline \multirow{2}{*}{\multicolumn{2}{|c|}{$\mathrm{TiO}_{2}$ nanoparticles }} & \multirow{2}{*}{\multicolumn{2}{|c|}{ Bacterial isolate }} \\
\hline & & & \\
\hline \multirow{2}{*}{$\begin{array}{l}\text { First } \\
\text { Run }\end{array}$} & Concentration & $50 \%$ & $50 \%$ \\
\hline & $\begin{array}{l}\text { Inhibition diameter } \\
(\mathrm{mm})\end{array}$ & 20 & 5 \\
\hline \multirow{2}{*}{$\begin{array}{l}\text { Second } \\
\text { Run }\end{array}$} & Concentration & $100 \%$ & $100 \%$ \\
\hline & $\begin{array}{l}\text { Inhibition diameter } \\
(\mathrm{mm})\end{array}$ & 25 & 10 \\
\hline
\end{tabular}

The titanium oxide nanoparticles $\left(\mathrm{TiO}_{2}\right)$ showed inhibitory efficacy at concentrations of $(50 \%-100 \%)$ against isolated and antibiotics multi-resistant bacteria. It was noted that the titanium dioxide nanoparticles have an effective antibacterial effect against both Gram negative and positive bacteria. In addition, when using $50 \% \mathrm{TiO}_{2}$ concentration, the inhibition diameter was $20 \mathrm{~mm}$ for Staphaureus, while it was $5 \mathrm{~mm}$ for Ps.aeruginosa, Table 3 . Fortunately, $\mathrm{TiO}_{2}$ concentration of $100 \%$ was more effective inhibitor for both Staphylococcus and Pseudomonas aeruginosa. Thus the inhibition of bacterial growth was dose dependent, which may interfere with host cell function. The present study finding was agreed with the previously reported studies [15-21]

Determination of synergistic inhibitory activity of titanium dioxide nanoparticles $\left(\mathrm{TiO}_{2}\right)$ and antibiotic resistance

Table 4 shows that the combination of $\mathrm{TiO}_{2}$ nanoparticles and antibiotics (AZM, MET and N) is with synergistic inhibitory effect against the tested bacterial isolates. The inhibitory diameters for Strep. pyogenes isolates were $50 \mathrm{~mm}, 40 \mathrm{~mm}$ and $20 \mathrm{~mm}$ at $50 \%$ concentration when combined with different antibiotics. While they are $50 \mathrm{~mm}, 50 \mathrm{~mm}$ and $30 \mathrm{~mm}$ at $100 \%$ concentration which indicate that the doubling of concentration not add any synergistic effect. Additionally, the inhibition diameter of Staph. saprophyticus isolates at $50 \%$ concentration were $30 \mathrm{~mm}, 25 \mathrm{~mm}$ and $20 \mathrm{~mm}$, which is not increased at $100 \%$ concentration. The same pattern was demonstrated by Staph. epidermidis. Thus this results indicated that combination of 
nanoparticles with antibiotic at 50\% concentration is with synergistic effect which may be suggested for treatment of infections induced by the tested bacteria. Additionally, the combination of nanoparticles and antibiotics (AZM, MET and N) may be suggested as alternative therapeutic approach for the treatment of infection induced by multiple resistant bacteria [22-26].

Table.4. Inhibitory activity of interference between $\mathrm{TiO}_{2}$ nanoparticles and antibiotics used against gram negative and gram positive bacterial isolates

\begin{tabular}{|c|c|c|c|c|c|c|}
\hline \multirow{2}{*}{$\begin{array}{c}\text { Bacterial } \\
\text { isolates }\end{array}$} & \multicolumn{6}{|c|}{ Inhibition diameter in $\mathbf{m m}$} \\
\hline & 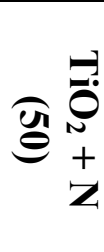 & 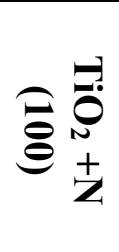 & 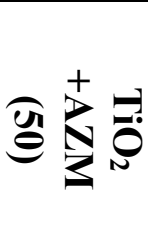 & 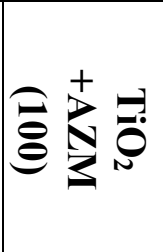 & 㫜 & 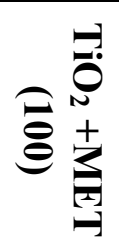 \\
\hline $\begin{array}{l}\text { Streptococcus } \\
\text { Pyogenes }\end{array}$ & 50 & 50 & 40 & 50 & 20 & 30 \\
\hline $\begin{array}{l}\text { Staphylococcus } \\
\text { saprophyticus }\end{array}$ & 30 & 30 & 25 & 25 & 20 & 20 \\
\hline $\begin{array}{l}\text { Staphylococcus } \\
\text { epidermidis }\end{array}$ & 35 & 35 & 25 & 25 & 20 & 20 \\
\hline $\begin{array}{l}\text { Staphylococcus } \\
\text { Aureus }\end{array}$ & 35 & 35 & 35 & 35 & 30 & 30 \\
\hline $\begin{array}{l}\text { Klebsiella } \\
\text { Oxytoca }\end{array}$ & 30 & 30 & 30 & 30 & 30 & 30 \\
\hline $\begin{array}{l}\text { Raoultella } \\
\text { ornithinolytica }\end{array}$ & 20 & 20 & 30 & 30 & 20 & 20 \\
\hline
\end{tabular}




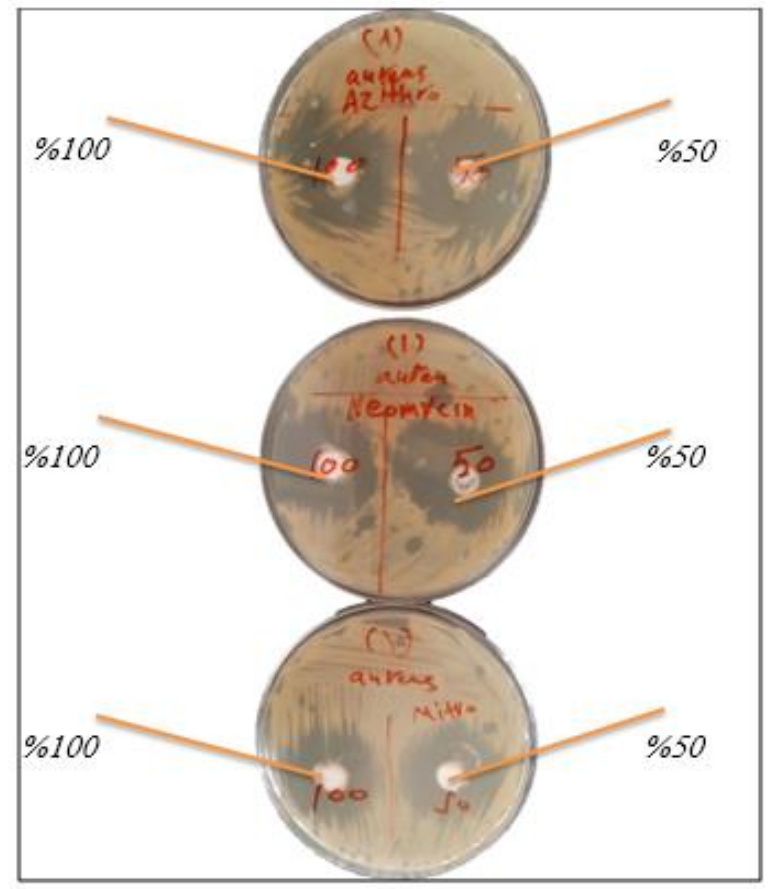

Figure. 2. Synergistic inhibitory activity of $\mathrm{TiO}_{2}$ nanoparticles and some multi-resistant antibiotics toward Staph. Aureus bacteria

The gram positive bacterial isolates showed that the synergy inhibition diameters of $\mathrm{TiO}_{2}$ molecules and the antibiotics (MET, N, AZM) against Strep. pyogenes isolates were (50,40 and 20) $\mathrm{mm}$ at a concentration of $50 \%$; and reached $(50,50$ and 30$) \mathrm{mm}$ at the concentration of $100 \%$. While the inhibition diameter of Staph. saprophyticus isolates at the concentration of $50 \%$ were $(30,25$ and 20) $\mathrm{mm}$; and reached $(30,25$ and 20$) \mathrm{mm}$ at $100 \%$ concentration. For Staph. epidermidis isolates, inhibition diameters were $(35,25$ and 20) at both concentrations of $50 \%$ and $100 \%$. Whereas, the inhibitory diameters of Staph.aureus isolates at the 50 and $100 \%$ concentrations were $(35,35$ and 30$) \mathrm{mm}$.

The gram negative bacterial isolates showed that Klebsiella oxytoca inhibition diameter was $30 \mathrm{~mm}$ at both concentrations $50 \%$ and $100 \%$. The inhibiting diameters of the Raoultella ornithinolytica 
isolates reached $(20,30$ and 20$) \mathrm{mm}$ at the two concentrations of $50 \%$ and $100 \%$, Table 4 .

$\mathrm{TiO}_{2}$ nanoparticles combination with antibiotics (MET, AZM, and $\mathrm{N}$ ) as treatment approach for bacterial infections is a promising alternative as this study indicated and the conclusions of previously reported studies [22-26]

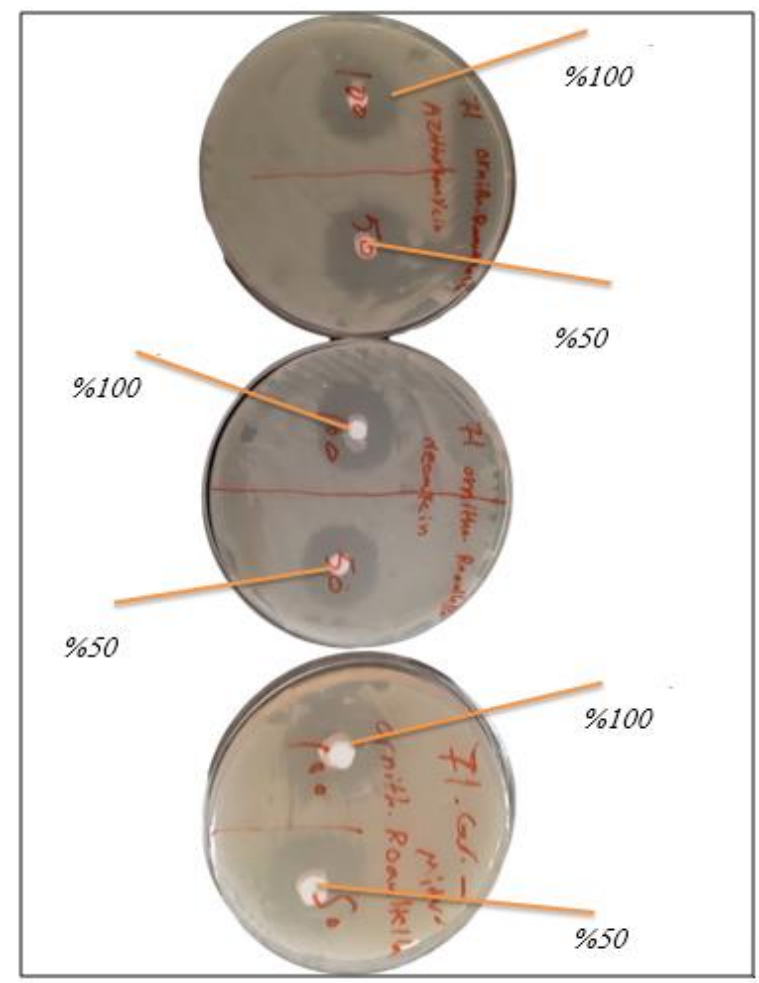

Figure. 3. Synergistic inhibitory activity of $\mathrm{TiO}_{2}$ nanoparticles and some multi-resistant antibiotics toward Raoultella ornithinolytica bacteria

\section{Conclusions}

1. Staph.aureus was the common bacterial isolate $(35.48 \%)$ of the gram-positive bacteria from acne lesions. While, Citrobacter freundii was the predominant of the gram negative species $(8.06 \%)$ in acne lesion. This may attributed to the modulation of the treatment approach of acne. 
2. Staph. aureus isolates from acne lesion show ability to produce all tested virulence factors (Hemolysin, Urease, Biofilm, Lecithinase, Lipase and $\beta$-Lactamase). While this character not demonstrated by other gram positive and gram negative bacterial isolates. This phenomenon may hurdle the acne treatment approach and may be responsible for high rate treatment failure.

3. The gram positive isolates were $100 \%$ resistant to Piperacillin, Azetreonam, Carbenicillin, Neomycin, while some gram negative isolates such as Pseudomonas species, Klebsiella oxytoca and Raoultella ornithinolytica were $100 \%$ resistant to Metronidazole, Piperacillin, Azetreonam, Carbenicillin, Neomycin, Azithromycin

4. The concentration of $100 \%$ nanoparticles of titanium dioxide showed very high inhibitory efficacy of $25 \mathrm{~mm}$ against Staph.aureus while with less inhibitory effect against Pseudomonas aeruginosa $(10 \mathrm{~mm})$.

5. The highest inhibition diameter of $50 \mathrm{~mm}$ was when the neomycin combined with $\mathrm{TiO}_{2}$ nanoparticles at $50 \%$ and $100 \%$ concentrations against Strep. pyogenes and the lowest inhibitory activity was 20 $\mathrm{mm}$ in diameter when metronidazole combined with $\mathrm{TiO}_{2}$ nanoparticles at $50 \%$ and $100 \%$ concentrations against Staph. saprophyticus and Neomycin with Raoultella ornithinolytica.

\section{References}

1. Vogt K, Herman J, Blume G, Gollnick H, Habin H. Haustein VF, Orfanos CE. Comparative activity of topical quinolone OPC7251. Against bacteria associated with acne vulgaris. Eur J Clin Microbiol Infect Dis, 1992;11(10): 934- 945.

2. Zhanel GG, Homenuick K, Noveddin A, Nichol K, Vercaigne L, Eruhil J, et al. The glycyclines; A comparative review with the tetracyclines. Drugs 2004;64(1):6388.

3. San-Jay N. Acne messages; crack the code of zits and say goodbye to acne. Noixias Reading Circle, 2004;pp 224

4. Brock DH, Madigan MT, Martinko JM, Parker J. Biology of Microorganisms. Prentice- Hall Inc Eagle wood cliffs, New Jersey, 1994;pp.528- 530.

5. Prescotte LM, Harley JP, Klein DA. Microbiology. McGraw Hill, New York, 2005; pp.992. 
6. Baron EJ, Peterson LR, Feingold SM. Diagnostic Microbiology. 15th ed. The C.V. Mosby Co. Toronto. Canada, 1998.

7. Eichenfield LF, Del Rosso JQ, Mancini AJ, Cook-Bolden F, Gold LS, Desai S, Kircik L. Evolving perspectives on the etiology and pathogenesis of acne vulgaris. J Drugs Derm, 2015;14(3):263268.

8. Forbes BE, Sahm DF, Weissfeld AS. Diagnostic Microbiology 11th ed. Mosby, USA,2002.

9. Collee JG, Miles RS, Watt B. Test for The Identification of Bacteria. P.131-149. In: JG Collee, ; AG Fraser; BP Marmion; S Simmons (eds.). Mackie and McCarteny Practical Medical Microbiology. 14th.ed. Churchill Livingstone, New York, 1996.

10. Koneman EW, Allen SD, Janda WM, Schreckenborger PC, Winn WC. Color plate and textbook of diagnostic microbiology. 4th ed. 1992, PP 405 - 429. J.B. Lippinnocott Company. Washington.

11. Freeman DJ, Falkiner FR, Keane CT. New method for detecting slime production by coagulase negative Staphylococci. J Clin Path 1989;42:872-874.

12. Bensons AEB. Microbiology Applications. 9th ed. Laboratory manual in general complete version. McGraw-Hill companies .New York.2005.

13. Hassouni AI. Determination of Inhibitory and Immuno- molecular Effect for $\mathrm{TiO} 2$ nanoparticles produced by some of microbes toward some types of pathogenic bacteria. $\mathrm{PhD}$ thesis. College of Pure Sciences, Tikrit University.2019.

14. Tarafdar A, Raliya R, Wang WN, Biswas P, Tarafdar JC. Green Synthesis of $\mathrm{TiO} 2$ Nano-Particles using Aspergilles tubingensis. Advanced Sciences, Engineering Medicine,2013; 5(9): 943-949.

15. Dicastillo CL, Correa MG, Martinez FB, Streitt C, Galotto MJ. Antimicrobial effect of titanium dioxide nanoparticles. In: Antimicrobial Resistance, January $27^{\text {th }} 2020$.

16. Azizi-Lalabadi M, Ehsani A, Divband, B., Sani MA. Antimicrobial activity of Titanium dioxide and Zinc oxide nanoparticles supported in $4 \mathrm{~A}$ zeolite and evaluation the morphological characteristic. Sci Rep 9, $17439 \quad$ (2019). https://doi.org/10.1038/s41598-019-54025-0

17. Allahverdiyev AM, Abamor ES, Bagirova M, Rafailovich $M$. Antimicrobial effects of $\mathrm{TiO} 2$ and $\mathrm{Ag} 2 \mathrm{O}$ nanoparticles against 
drug-resistant bacteria and leishmania parasites. Future microbiology 2011;6:933-940.

18. Besinis A, De Peralta T, Handy RD. The antibacterial effects of silver, titanium dioxide and silica dioxide nanoparticles compared to the dental disinfectant chlorhexidine on Streptococcus mutans using a suite of bioassays. Nanotoxicology 2014; 8:1-16.

19. Rajakumar G, Abdul Rauman A, Mohana Roopan S, Khanna VG, Elango G, Kamaraj C, et al. Fungus-mediated biosynthesis and characterization of $\mathrm{TiO} 2$ nanoparticles and their activity against pathogenic bacteria. Spectrochimica Acta Part A, Molecular and Biomolecular Spectroscopy 2012;91:23-29.

20. Vincent MG, John NP, Narayanan PM, Vani C, Murugan S.

In vitro study on the efficacy of zinc oxide and titanium dioxide nanoparticles against metallo beta-lactamase and biofilm producing Pseudomonas aeruginosa. J Appl Pharmaceut Sci 2014; 4 (07):41-46.

21. Landage KS, Arbade GK, Khanna P, Bhongale CJ. Biological approach to synthesize $\mathrm{TiO} 2$ nanoparticles using Staphylococcus aureus for antibacterial and antibiofilm applications. J Microbiol Exp. 2020;8(1):36-43.

22. Abdulla RM. A Study the Effect of $\mathrm{TiO} 2$ Nanoparticles Combination with Antibiotics and Plant extracts Against Some Gram Negative Bacteria. Baghdad Sci J 2016;13(3):425-434.

23. Roy A, Parveen A, Koppalkar A, Prasad M. Effect of Nano Titanium Dioxide with Different Antibiotics against MethicillinResistant Staphylococcus Aureus. J Biomaterials Nanobiotechnology. 2010;1(1):37-41.

24. Arora B, Murar M, Dhumale V. Antimicrobial potential of $\mathrm{TiO} 2$ nanoparticles against MDR Pseudomonas aeruginosa. J Experimental Nanoscience, 2015;10(11):819-827.

25. Shaikh S, Nazam N, Rizvi SM, Ahmad K, Baig MH, Lee EJ, Choi I. Mechanistic Insights into the Antimicrobial Actions of Metallic Nanoparticles and Their Implications for Multidrug Resistance, Int J Mol Sci. 2019;20:2468; doi:10.3390/ijms20102468

26. de Dicastillo CL, Patiño C, Galotto MJ, Vásquez-Martínez Y, Torrent C, Alburquenque D, et al. Novel hollow titanium dioxide nanospheres with antimicrobial activity against resistant bacteria. Beilstein J. Nanotechnol. 2019:10:1716-1725. 